\title{
Terrorism Studies in International Business: Increasing Knowledge, Reducing Victimization
}

\author{
Gabriele Suder, SKEMA Business School, France \\ Michael Czinkota, Georgetown University, USA
}

WE SUGGEST THAT TERRORISM STUDIES have become an integral part of the international business (IB) literature, despite the difficulties inherent in its research, and that the (ongoing) consolidation of this literature stream now provides IB researchers and practitioners with an affluence of insights to benefit from in the future.

\section{From windmills to ugly faces}

Terrorism analyses have been part of research in the fields of political science, geopolitics and criminology for centuries. In business studies, the phenomenon was typically scrutinized in a limited manner, mainly under a financial or political risk management and insurance perspective and, by some, as one of several potential triggers of disaster management.

In the IB arena, barely any research made reference to terrorism before 9/11/2001; if so, studies were resolutely country- and sector- specific, mostly revolving around attacks on commodities or tourism. Terrorism was not seen as a business-relevant problem where business could bring a solution. It was mainly framed in terms of protection from the, mostly limited, effects of terrorism. As to whether business could either prevent or trigger terrorist activities was not part of the field's concern.

A new era of terrorism in terms of level of intensity, reach, target and location, particularly since the tragic events of 9/11/2001, changed sensitivities. This also generated increasing attention to terrorism issues in the academic work on the internationalization of the firm. A new stream of literature, launched by only a handful of IB researchers, led to a growing number of academics and practitioners who have dedicated their work to the analyses of terrorism from various points of view and with a more global business perspective. They have created a body of contributions that now advances our understanding of the phenomenon, its impact and resulting strategic implications for the international firm.

Yet, early contributors had to fight against the windmills of opposition to qualitative research, adversity founded in data limitations and the lack of a conceptual cradle. They thus had set out to embed their projects in the works of scholars including Mascarenhas (1992), who had stressed the particular exposure of international business operations to uncertainty, emphasizing the significance of managers' perceptions and judgment. Similarly, Kobrin's (1992) work on political risk associated with foreign investment became a basis for extended argumentation in the context of terrorism. The way in which such events affect the firm depends, to a large extent, on the managerial perceptions of events and outcomes, which, in turn, will guide resulting action. Weir (2002) examined manmade disasters and postulated that risky reactions by companies are contingent on the negligence of appropriate strategies, or worse, in the belief in "managerial triumphalism."

However, any type of terrorism greatly increases the level of uncertainty in the complexity of international business (Enderwick, 2001; Suder \& Czinkota, 2007). Global terrorism fosters a modification of perceptions, scale and scope of stakeholders, and it questions the universality of corporate tactics. 9/11/2001 and subsequent Western incidents of global terrorism have taught important lessons. General managers and strategists allow international business to look into the ugly face of terrorism and to yield paybacks from appropriate strategy rather than passively ache from unexpected tragedy. While the human sufferance caused by terrorists can and will never be neglected or excused by managers, international business theory and practice can play an vital part of prevention and harm limitation by not caving into their goals.

\section{What changed on a conceptual level...}

...was, first of all, the perception of risk and uncertainty. The scale, scope and target of 09/11/2001-induced terrorism, in its ugliness, has advanced international business understanding and capabilities. Terrorism has moved to the rank of a risk that needs to be assessed, evaluated and managed, and that the international firm of any sector needs not bear passively. The Boston Marathon attack has reminded the international events management and sports sector of this cruel reality.

The key objective of contemporary terrorism is the most efficient distribution of unexpected violence and the threat of violence against civilians that are (directly or indirectly) part of economic organizations and structures. The effect is maximized through the victimization of innocents and patrons of what they see as the capitalist world, and that a maximum of onlookers can identify with. More than a decade of experience with the new nature of this terrorism has triggered the increasing resilience of global and regional economic flows and forced firms to design new strategic adaptations. 
One other recent example is the attack against gas exploitation sites in Algeria. Again, keeping international investors away from certain locations, disrupting value chains, spreading perpetual fear are meant to form an omnipresent and widespread threat.

As a result, for international business, global terrorism analyses have soared in importance and "terrorism" has changed from a mainly nonprobabilistic uncertainty to a risk in its own name. As a management variable, terrorism has been entering the broad levels of corporate strategy and leadership. Marketplace, infrastructure, financial and reputational risks that many firms use to scrutinize domestically for their firm's scorecard, have been adapted to global challenges largely ignored (or at least, limited) until 2001. They are now directly linked to the firm's international environments and internationalization process, transac- physical level. This level is mainly explored and conceptualized in the literature and includes business continuity planning/preparedness (Jrad et al., 2004; Zsidisin, Melnyk \& Ragatz, 2005), business resilience (Enderwick, 2006; Sheffi, 2005), crisis management, disaster recovery (Decker, 2005) and disaster planning (Gerber \& Feldman, 2002).

The analysis of indirect effects includes the examination of demand and supply effects, international transactions costs, international supply chains resilience and flexibilities, reputations, government policies, regulations, procedural changes (e.g., customs, migration, M\&A policy) and the trends and flows of FDI and corporate internationalization strategy over time (Czinkota et al., 2010; Suder, 2004).

Interestingly, from the very cradle of such analyses, scholars and practitioners have recognized that the high perception of threat and uncertainty caused by terrorism may lead not only to loss but also to the creation of new business opportunities (Enderwick, 2001). This understanding was primarily grounded in observations of advantages yielded in the field of security, protection, insurance and risk management technologies. The redistribution of profit and revenue has characterized many sectors such as tourism, protection service providers or image collection and comparison firms. Global terrorism shapes FDI (re-)distribution, modifies (more modifiable) location decisions, and alters the scale and scope of global value chains

The risk-return evaluation literature has added further insights into IB considerations, with some dilemmas and ambiguities. Two streams of research motivated by the negative risk return association have come into play to a somewhat insufficient degree: one stream results from a combination of the utility theory of Schoemaker (1982), prospect theory of Kahneman and Tversky (1979) and Bowman's (1980) "risk-return paradox"; the other one, more process oriented, was initiated by Bromiley (1991) and Wiseman and Bromiley (1996) with the link between productivity increase and risk taking. However, in the international business literature, the risk/return evaluation conceptual frame investigates terrorism analysis and assessment, using empirical findings, to demonstrate that strategic choices are increasingly taking into account in a positivation of this global risk return evaluation, to help mitigate the risks and yield benefits despite of (or sometimes, thanks to) extreme contexts (Branzei \& Abdelnour, 2010; Kotabe, 2005; Suder et al., 2013).

\section{Managerial issues}

Today, firms consistently rate the uncertainty triggered by terrorism as high, and they undertake specific measures to reduce such risk (Czinkota \& Ronkainen, 2009)

Mascarenhas (1982), in an early Journal of International Business Studies (JIBS) article, has already stipulated that only a systematic procedure for 
reducing uncertainty can function efficiently to secure corporate performance in the long term, and had placed special emphasis on the methods of control and flexibility in qualitative research with MNEs. Kobrin (1992) added that strategy depends on whether the risk is systematic or not. Other methods of influencing uncertainty include non-market strategy, corporate social responsibility policies and social innovation.

In addition to the extension of these early works, the surveys of managerial assessment and evaluation of political, geo-political and geo-economic environments have extended terrorism research. In a nutshell, corporations today strive to include terrorism's impact (as one of several key issues of international stability) into their strategic planning and the (re-) configuration of international business activity, using three levels of analysis. First, there is the primary level, where the most immediate and direct consequences of a terrorist action are investigated. Second is the micro-level of analysis where specific regions, industries, or performance levels in international value chains are scrutinized over time. The third one is the macro level, where short-, mediumand long-term global shifts and adjustments are considered, and linked to corporate identity risk exposure analysis. The core of this latter concept is the idea that identity is based on a specific set of variables that determines (terrorism) risk exposure. Variables likely to affect the risk of a particular company as opposed to the risk from the environment will include the products and services a firm offers; the sector in which it operates; the strength of its brand image; the perceived country of origin; the location of its head office; its past behavior; its link to alien cultural values; its perceived size and wealth and the lore associated with the creation of such wealth.

\section{Current research and practice: Future perspectives}

The international business literature took some time to acknowledge the importance of global terrorism risks and its impact on international commerce and corporations. This occurred not because of insufficient scholarly awareness of the significance of terrorism. Rather, the difficulty in obtaining company primary data regarding highly sensitive issues surrounding terrorism and corporate preparedness for it had drawn a barrier to early scholarly analysis that only a few researchers were able to transcend at that time. Also, the psychologically complex exposure to the phenomenon itself may be challenging, given that some significant research work required field work and on-the-ground interviews. Amongst the first to research and publish about contemporary global terrorism were Enderwick (2001), Trim (2003) and Suder (2004). Continued exploration of IB and terrorism issues centered on state-of-affairs analyses of direct impacts, the loss and adaptations in global terrorism aftermaths, followed by conceptualizations to model indirect impacts and the study of corporate strategies on a micro-and macro-level (Gillingham et al., 2008; Spich \& Grosse 2005; Suder 2006).
Today, big data have become available from previously confidential corporate and institutional sources. Since terrorism is no longer seen as unique and rare, more analyses are facilitating further insights and better understanding.

We have thus recently seen the emergence of various specific substreams of terrorism studies affiliated with IB studies. These include, for instance, the work of Branzei and Abdelnour (2010), who set out to explain the somewhat paradoxical observation (at first sight) that enterprise activities often flourish under extreme adversity. A study of internationalization into high-terrorism risk, institutionally incomplete business contexts proposed by Suder et al. (2013) scrutinizes related organizational and managerial absorptive capacity from a learning perspective. Getz and Oetzel (2010) analyzed MNE strategic intervention in adverse conditions of uncertainty and violent conflict. Yet other studies propose insights into the indirect effects of terrorism on brand value and rankings; compare terrorism to financial risk effects, or conduct investigations into the building of social networks to help broaden manager's capabilities of dealing with terrorism. We now even see statistical analyses that endeavor to uncover the relation between terror and corporate performance, measured for instance by return on equity (ROE) (Suder \& Czinkota, 2013). Finally, as a growing availability of big data emerges, research needs to distinguish more between groups of international businesses.

Some limitations to corporate awareness (and thus, barriers to learning and adaptation) have nonetheless been revealed. Certain types of corporations are likely to tackle the terrorism threat head-on and strive to adapt and strategize (e.g., firms that compete in risky locales), while other firms, be it out of lack of immediate necessity, ignorance or insufficient motivation, have less incentive to dedicate themselves to the repulsion and prevention of terrorism. They are thus more vulnerable in the long term. Also, there is concern that corporate attention to and adaptive strategies for addressing terrorism are correlated to the frequency and geographic relevance of terrorist events.

Overall, the study of terrorism and its context for international firms has become an integral part of the IB literature, despite the difficulties inherent in its research. The consolidation of this literature stream now provides international business researchers and practitioners with insights for use in continued work. Terrorism itself will hopefully suffer from this enhanced knowledge, which, over time may lead to knowledge resulting in the containment of victimization in the future. 


\section{References}

Bowman E. H. 1980. A risk-return Paradox for Strategic Management. Sloan Management Review, 21(3): 17-31.

Branzei, O., \& Abdelnour, S. 2010. Another day, another dollar: Enterprise resilience under Terrorism in Developing Countries. Journal of International Business Studies, 41: 804-825.

Bromiley, P. 1991. Testing a causal Model for Corporate Risk taking and Performance? Academy of Management Journal, 34: 37-59.

Czinkota, M. R. 2002. From Bowling Alone to Standing Together. Marketing Management, March/April: 12-16.

Czinkota, M. R., Knight, G. A., \& Liesch, P. W. 2004. Terrorism and international business: conceptual foundations. In G. Suder, (Ed.), Terrorism and the International Business Environment. The Security Business Nexus: 43-57. Edward Elgar Publishing.

Czinkota, M., Knight, G., Liesch, P. \& Steen, Y. 2006. Positioning Terrorism in Marketing: Research Propositions. Journal of International Management, 11(4): 581-604.

Czinkota, M. R., \& Ronkainen, I. A. 2009. Trends and Indications in International Business. Management International Review, 49(2): 249-265.

Czinkota, M. R., Knight, G., Liesch, P.W., \& Steen, J. 2010. Terrorism and international business: A research agenda. Journal of International Business Studies, 41(5): 826-843.

Decker, A. 2005. Disaster recovery: What it means to be prepared. DM Review, 15(1): 44-46.

Dun, G. 2003. Forecasting Global Terrorism. World Markets Research Centre, PowerPoint Presentation, October.

Dunning, J. H. 2000. The Eclectic Paradigm as an Envelope for Economic and Business Theories of MNE Activity. International Business Review, 9(2): 163-190.

Enderwick, P. 2001. Terrorism and the international business environment. AlB Insights, Special Electronic Issue 2-6, http://aib.msu. edu/publications/insights/archive/insights_special.pdf.

Enderwick, P. 2006. Managing the new global threats. University of Auckland Business Review, 8(2): 63-72.

Fernandez, E. 2010. Unsuccessful responses to quality uncertainty: Brands in Spain's sherry industry, 1920-1990. Business History, 52(1): 100-119.

Getz, K. A., \& Oetzel, J. 2010. MNE Strategic Intervention in Violent Conflict: Variations Based on Conflict Characteristics. Journal of Business Ethics, 89(S4): 375-386.

Gerber, J. A., \& Feldman, E. R. 2002. Is your business prepared for the worst? Journal of Accountancy, 193(4): 61-64.
Gillingham, D., \& Suder, G. 2008. Corporate Strategies for Countering Security Risks. In A. W. Merkidze, Terrorism issues, threats, assessment, consequences and prevention: 201-212. New York: Nova Science.

Jrad, A., Morawski, T., \& Spergel, L. 2004. A model for quantifying business continuity preparedness risks for telecommunications networks. Bell Labs Technical Journal, 9(2): 107-123.

Kahnemann, D., \&Tversky, A. 1979. Prospect Theory: An Analysis of Decisions under Risk. Econometrica, 47: 262-291.

Kobrin, S. 1976. The Environmental Determinants of Foreign Direct Manufacturing Investment: An Ex-Post Empirical Analysis. Journal of International Business Studies, Fall/Winter: 29-42.

Kobrin, S. 1992. Political risk: A review and reconsideration. MIT: 67-80.

Kotabe, M. 2005. Global security risks and international competitiveness. Journal of International Management. 11 (4): 453-455.

Mascarenhas, B. 1982. Coping with Uncertainty in International Business. Journal of International Business Studies, 13(2): 87-98.

Schoemaker, P. J. 1982. The Expected Utility Model: Its Variants, Purpose, Evidence and Limitations. Journal of Economic Literature, 20: 529-563.

Sheffi, J. 2005. The resilient enterprise: Overcoming vulnerability for competitive advantage. Boston, MA: MIT Press.

Spich, R., \& Grosse, R. 2005. How does homeland security affect US firms' international competitiveness? Journal of International Management, 11(4): 457-478.

Suder, G. (Ed.) 2004. Terrorism and the International Business Environment. The Security Business Nexus. Cheltenham and Nottingham: Edward Elgar.

Suder, G. 2004. The complexity of the geopolitics dimension in risk assessment for international business. In G. Suder (Ed.), Terrorism and the International Business Environment-A Security-Business Nexus. Cheltenham/Northampton: Edward Elgar.

Suder, G. 2004. Panel Paper: Building Bridges under Conditions of Adversity: The Complexity of the Geopolitics Dimension in Risk Assessment for International Business. Academy of International Business Annual conference 2004, Stockholm.

Suder, G. 2006. Corporate Strategies under International Terrorism and Adversity. Cheltenham and Nottingham: Edward Elgar.

Suder, G. 2008. International Business under Adversity: A Role in Corporate Responsibility, Conflict Prevention and Peace. Cheltenham and Nottingham: Edward Elgar.

Suder, G., \& Czinkota, M. 2007. Towards an understanding of terrorism risk in the MNE. Multinational Business Review, 13(3): 3-23. 
Suder, G., \& Czinkota, M. 2013. Terror and Return on Equity: Evidence of the Impact of Global Terrorism on Corporate Profitability, work-inprogress.

Suder, G., \& Suder, D. 2013. The effect of macroeconomic threats on brand value and ranking: Insights from 10 years of fluctuations, Journal of Brand Management, 20: 309-324.

Wells, L. 1998. Good and Fair Competition: Does the Foreign Investor Face Still Other Risks in Emerging Markets? In T. H. Moran (Ed.), Managing International Political Risk: 15-43. Malden, MA: Blackwell Publishers.

Wiseman, R. M., \& Bromiley, P. 1996. Towards a Model of Risk in Declining Organizations: an Empirical Examination of Risk, Performance and Decline. Organizational Science, 7: 524-543.

Zsidisin, G. A., Melnyk, S. A., \& Ragatz, G. L. 2005. An institutional theory perspective of business continuity planning for purchasing and supply management. International Journal of Production Research, 43(16): 3401-3420.
Gabriele Suder is Jean Monnet Chair Professor of International Business at SKEMA Business School and Academic Director for SKEMA US, Raleigh, NC. She has been with SKEMA (nee CERAM) since 2002. Dr. Suder holds a German BA in Economics, Politics, Chinese and Japanese, an MPhil in Governmental Studies from the University of Strathclyde, and a PhD in Management from the University of Bath, UK. She is also a graduate of ITP at IMD Lausanne in 2008. For SKEMA, Gabriele teaches mainly in Sophia Antipolis, Raleigh, and Suzhou. Gabriele has been a visiting fellow at Australia National University European Studies Center, and regularly teaches at Aalto University, Finland and at GGS, Germany. She served as external examiner of ESCP-Europe's multi-campus Master in Management/MBA programme, as expert at the European Union for Education and 'Lifelong Learning', and at UNCTAD for Investment Trends (WIR). She publishes widely and appears regularly on national and international radio and TV for interviews. She is particularly well known for her early IB research publications on global terrorism and internationalization strategy in regional contexts. Gabriele joins the University of Melbourne as Director, International Relations, in early 2014.

Michael Czinkota is an Associate Professor at McDonough School of Business, Georgetown University. He has been listed in the leading ranks of prolific authors in $\mathrm{IB}$, and is lead author of two major textbooks (International Business 8th ed. Wiley and International Marketing 10th ed. Cengage) He has served the U.S. government as Deputy Assistant Secretary of Commerce responsible for Trade Information and Analysis. Educated in Germany, Austria, Scotland, and the United States, Czinkota holds an MBA and Ph.D. in international business and logistics from The Ohio State University. 